\title{
RECONSTRUCTION OF DECISION BAPEPAM-LK N0.412/BL/2010 CONCERNING ON THE TRUSTEE CONTRACT
}

\author{
Elvira Fitriyani Pakpahan \\ Faculty of Law University Prima Indonesia \\ elvirapakpahan@unprimdn.ac.id \\ Bambang Tri Bawono \\ Faculty of Law Unissula \\ bambang@unissula.ac.id \\ Azharuddin \\ Faculty of Law University Prima Indonesia \\ azharuddin@unprimdn.ac.id
}

\begin{abstract}
The purpose of this study reconstructs Bapepam-LK's decision number 412 / BL / 2010 concerning the trustee contract refers to specific provisions on guarantees stipulated by Bapepam / FSA as in item 4 letter $E$ which is still too common. Conditions of bail in number 4 letter $E$ Bapepam Decree 412 is only limited provision of information, not a necessity. Password Security (if any) does not provide legal certainty for investors obligations in case of default. With juridical sociological research methods. The theory used to analyze the theory of justice that is dignified, then research the reconstruction of the law done by changing the special provisions Bapepam's Decision No. 412 in number 4 letter E on collateral (if any) by removing / deleting the words in brackets (if any), caused not show the certainty justice and dignity justice.
\end{abstract}

Keyword: Decision of Bapepam-LK, Reconstruction, Trustee Contract.

\section{A. INTRODUCTION}

Case of default in obligation trading into a problem that is happening in the Indonesian economy and become serious because it can degrade the economy, especially in the capital market. The cases of default showed that several companies have been in default of investors with obligation holders by not paying the principal and / or interest on corporate obligations according to the agreement that has been determined and agreed upon in advance. The companies that are declared in default can not be paying interest on corporate obligations is likely to have two (2) issues the company for the time being does not have the cash to pay the principal and 
/ or interest on the obligations the company or companies are no longer able to pay the principal and / or the corporate obligation interest. ${ }^{1}$

Case of default by the issuer the issuer company is very detrimental to investors holding the obligations, the contractual relationship of the parties in the obligation agreement thus does not reflect the relationship that is based on justice. In effect the contractual relationship can not be released in conjunction with the issue of justice. Contract as a container that reconcile the interests of one party with another party to form a fair exchange of interests. In contractual between the issuer issuer to investor obligationholders essentially be based on basic principles of contract law and the theory of justice as a foundation in the contract.

Article 8 paragraphs 2 and 3 of Act No. 24 of 2002 concerning Government Obligation declared Paragraph (2) The Government shall pay interest and principal each Government Securities at maturity. Paragraph (3) Funds to pay interest and principal as referred to in paragraph (2) is provided in the State

1 Elvira Fitriyani Pakpahan, Rekonstruksi Pengaturan Obligasi di Pasar Modal Indonesia Berbasis Keadilan, (Semarang: Disertasi, 2017), p 22
Budget every year until the end of the obligations. It is already showing legal certainty for investors who will invest in state obligations. ${ }^{2}$ However, for private or corporate obligation investment regulations regarding inadequate obligation. Basically, stock and obligation trading difference lies in the trustee as a third party bridge between investors and issuers. And in the trade must be a trustee contract is in accordance with Article 52 of Act No. 8 of 1995 on Capital Markets stating the issuer and trustee trustee must make a contract in accordance with the provisions made by Bapepam.

The article indicates that the obligation transactions in the capital market to make a contract as a benchmark. Because it is a legal protection for investors, when something happens as a result of missapropriation issuers to investors. Article 53 of Act No. 8 of 1995 on Capital Markets "Trustee shall provide compensation to the holders of debt securities for losses due to negligence in the performance of its duties as stipulated in this Law and its implementing regulations as well as

2 Elvira Fitriyani Pakpahan, 2009, ORI dalam Perspektif Hukum di Indoneisia, La Tansa Pers, Medan p.9. 
trustee contract," and in tune with the Decree of Bapepam-LK No. 412 / BL / 2010 on general provisions and trustee contract debt securities, in the annex to the Regulation No. VI. C.4 Item 2 Liabilities Trustee letter (d):

The interesting thing to note is the sound of Item 4 of Regulation No. VI.C.4 In order to protect and represent the rights of the holders of debt securities, the Trustee shall make a contract with the Issuer Trustee which contains at least: $a$. The identities of the parties, b. Debt Principal, c. Debt Maturity Principal, d. Flowers, e. Warranties (if any), and others. Bapepam decision is deemed not give legal certainty to investors because it makes no warranties points becomes imperative. Whereas in the credit clearly stated the elements of the unsecured loans. Debt has a vulnerable element of time, and did not rule out new things will happen in the presence of such a vulnerable time for example the company insolvent and unable to pay interest and principal.

In spite of some interest of the government to cover the deficit Budget of the State each year through the issuance of government securities (GS) in the form of Retail Obligations
(ORI), which is considered necessary and very important for today's society is the knowledge of setting the issuance of state obligations retail in the legal provisions of Government obligations in Indonesia as well as on the status and legal protection for obligation holders, retail State. It is none other than to determine how much security and legal protection of the investments made in the form of obligations, because it does not rule out the possibility of default events Government Obligations under President Sukarno repeated.

In accordance with the purpose of the State of Indonesia to promote the general welfare of the government investment policies, especially in the field of reconstruction required obligation legislation in the field of obligations. Grundnorm Pancasila as the basis for the reconstruction of the legislation in the field of obligations. In order to create the essence of the state in the implementation of legislation in the field of obligations fairness should contain "legal justice" because the law should contain justice (ius quia iustum) that contains an order harmoniously. Justice is an ideal / of great value which must be upheld in the agreement relating to the 
obligations. Starting from the establishment of regulation (Regeling), decision makers or in the form of material action in the field of government obligations, both procedural and substantial action. The problem is how the reconstruction of Bapepam-LK's decision No. 412 / BL / 2010 concerning the trustee contract. With the aim to reconstruct the Bapepam-LK Decision No. 412 / BL / 2010 on Trustee contract because they do not give justice to investors in the capital market. The method used juridical empirical non-doctrinal, with the approach used is sociological / non positivistic empirical approach and analysis is qualitative. With the aim to reconstruct the Bapepam-LK Decision No. 412 / BL / 2010 on Trustee contract because they do not give justice to investors in the capital market. The method used juridical empirical non-doctrinal, with the approach used is sociological / non positivistic empirical approach and analysis is qualitative. With the aim to reconstruct the Bapepam-LK Decision No. 412 / BL / 2010 on Trustee contract because they do not give justice to investors in the capital market. The method used juridical empirical non-doctrinal, with the approach used is sociological / non positivistic empirical approach and analysis is qualitative.

\section{B. DISCUSSION}

Dignified justice theory is a theory of law that works by taking into account legal materials regulations that apply in a legal system, legal philosophy, theory, dogma and doctrines in the law and legal practices that took place in the system of positive law. The theory of justice dignified adheres to the principle that, in a doctrinaire or dogmatic law, there is a doctrine of legal discovery (rectsvinding) which follows the legal nature of the always progressive in the lining of the philosophy of law, legal theory, dogmatic laws and practices to preserve the values and morality. ${ }^{3}$

Judging from the theory of justice dignified by Prof. Teguh Prasetyo that the attraction between Lex Etema upper stream and lower stream volksgeis in understanding the law as an attempt to approach the mind of the Lord according to the legal system based on Pancasila. ${ }^{4}$

Pancasila has been stipulated as the first source and the foremost

3 Teguh Prastyo, 2015, Keadilan Bermartabat Perspektif Teori Hukum, Nusamedia, Bandung, p. 11-2.

4 Ibid. 
source of all sources of law is the which has been in force in the system of laws of the independent and sovereign nation state of Indonesia. The stipulation of the Pancasila as the first and foremost source of all sources of laws in the Indonesian legal system as such Might Be Considered as an indication of the fulfillment of the conditions in jurisprudence, theoretically, in doctrine, as well as in legal practice as Mentioned above. The stipulation as such, is also fair and logical in other than a system of law, such as the Indonesian system, ${ }^{5}$

It certainly should reflect justice in Indonesian society, especially in terms of the issuer's contractual obligation issuer with investors holding the obligations according to volksgeis in Indonesia. Three Common Characteristics Justice First, justice always focused on others or justice always marked of directness. Second, justice must be enforced or implemented. Thirdly, justice demands equality (equality). ${ }^{6}$

Contract law in Indonesia is regulated in Book III of the Civil Code Chapter Two, which governs the engagement-perikaan which is born of

5 Teguh Prasetyo, Pancasila The Ultimate of All the Sources of Laws (A Dignified Justice Perspective, Jurnal Internasional, The International Institute for Science, Technology and Education/ IISTE, Oktober 2016, p. 103.

6 Andre Ata Ujan, 2001, Keadilan dan Demokrasi: Telaah Filsafat Politik John Rawls, Kanisius, Yogyakarta, p 23. the contract or agreement. Definition of contracts with the agreement is the same as seen defined in Article 1313 of the Civil Code. Contract law only regulates certain aspects of the market and regulate certain types of agreements. ${ }^{7}$ Yet maybe the contract is less prominent part of the law of life (living law) than other areas of the growing popularity of contract law or thinking about contracts.

Renewal or reconstruction of the terminology has a wide range of understanding, in national development planning is often known as reconstruction. Reconstruction means that "re" means renewal while the "construction" as explained above has the meaning of a system or form. Some experts define reconstruction in various interpretations BN Marbun simply define the preparation or depictions back from existing materials and reassembled as is or original incident ${ }^{8}$, Whereas according to James P. Chaplin Reconstruction is a psychoanalytic interpretation of the data in such a way, to explain the personal development that has taken place, along with the meaning of the

7 Ibid. p.196.

8 B.N. Marbun, 1996, Kamus Politik, Pustaka Sinar Harapan, Jakarta, , p. 469 
material that now exist for the individuals concerned. ${ }^{9}$

Reconstruction in this study is the renewal of the system or form. Reconstruction Law is one way to enhance existing law to respond to changes in society. In addition it is also one way to develop the law or legal material posisitif through logical reasoning, in order to achieve the desired results. That is, the reconstruction of a restructure and synchronize several laws exist. In doing construction Scholten law gives attention to the three conditions, namely ${ }^{10}$ :

1. Reconstruction should be able to cover the entire field of positive law is concerned.

2. There should be no logical contradictions therein. For example, there is a doctrine that states that the owner could be the holder of the mortgage of his own goods. This teaching is wrong because construction manufacture its own mortgage is a right that belongs to someone on the property of others.

3. Reconstruction should qualify beauty. That is, it is something

9 James P. Chaplin, 1997, Kamus Lengkap Psikologi, Raja Grafindo Persada, Jakarta, p.421

10 Ibid. p. $103-104$ that is made-up should provide a clear and simple.

Through the concept of such reconstruction, the reconstructed Legal regulations are expected to be better and ensure legal certainty and beneficial to society. This became technically needs to be there in the law and the formation to achieve better process in the future.

The decision of Bapepam-LK No. Kep-412 / BL / 2010 stipulated in Rule Number VI.C.4 on general provisions and contract perwaliamantan debt securities 4 points to the trustee contract is necessary to be reconstructed because it does not give legal certainty. Password Security (if any) indicates the absence of legal certainty for obligation investors. Whereas a guarantee is one of the attractions for investors in addition to interest on the obligations. And not only that, the guarantee is very important for investors, given the obligation investment is not much different with the banking credit. Security is one of the elements in the credits. With the guarantee, then the value of the trust and of course the value of certainty more pronounced. There is no doubt for investors when 
investing in spite of any investment has risks.

Likewise with 2 points to the trustee obligations deemed necessary reconstructed, as just stated that the trustee shall replace losses due to negligence and regulations stipulated in the trustee contract. The words shall not accompanied by collateral that can provide legal certainty to the investment. Above all the absence of clear rules regarding what sanctions can be given to the trustee as a result of negligence. The absence of clear regulation in VI.C.4 regulation make a difference every contract perwaliamantan. In these regulations the issue of sanctions as expressly provided in the trustee contractship. But did not explain what sanctions could be given to the trustee in the event of default on obligation investments.

Reconstruction of Ideal Value Setting Obligations in Indonesian Capital Market

\begin{tabular}{|c|c|c|}
\hline No & about & Commentary \\
\hline 1. & $\begin{array}{l}\text { Basic } \\
\text { Reconstructio } \\
\mathrm{n}\end{array}$ & $\begin{array}{l}\text { Blending local } \\
\text { wisdom in } \\
\text { obligation } \\
\text { values and } \\
\text { precepts of }\end{array}$ \\
\hline
\end{tabular}

\begin{tabular}{|c|c|c|}
\hline & & $\begin{array}{l}\text { Pancasila, } \\
\text { namely two } \\
\text { and five } \\
\text { precepts of } \\
\text { Pancasila, the } \\
\text { Constitution of } \\
\text { the Republic of } \\
\text { Indonesia } \\
1945 \quad \text { Article } \\
33 \text {, paragraph } \\
4 \text { and Article } \\
28 \\
\text { paragraph } 1 \\
\text { and the value } \\
\text { of equity in } \\
\text { Pancasila with } \\
\text { international } \\
\text { wisdom. }\end{array}$ \\
\hline 2. & $\begin{array}{l}\text { The theory } \\
\text { used to } \\
\text { reconstruct }\end{array}$ & $\begin{array}{l}\text { Grand Theory: } \\
\text { Theory of } \\
\text { Dignity Justice } \\
\text { Middle Theory: } \\
\text { Theory } \\
\text { Protection } \\
\text { Appliaed } \\
\text { Theory: } \\
\text { Theory } \\
\text { Agreement }\end{array}$ \\
\hline $3 .$. & $\begin{array}{l}\text { Paradigm } \\
\text { reconstruction }\end{array}$ & $\begin{array}{l}\text { Constructivism } \\
\text {, which } \\
\text { reconstructs } \\
\text { the } \\
\text { implementatio }\end{array}$ \\
\hline
\end{tabular}




\begin{tabular}{|c|c|c|}
\hline & & $\begin{array}{l}\mathrm{n} \text { of } \\
\text { obligations in } \\
\text { the capital } \\
\text { market } \\
\text { regulation } \\
\text { based on } \\
\text { values of } \\
\text { justice }\end{array}$ \\
\hline 4. & $\begin{array}{l}\text { Objective } \\
\text { Reconstructio } \\
n\end{array}$ & $\begin{array}{l}\text { Strengthening } \\
\text { the } \\
\text { implementatio } \\
n \text { of the } \\
\text { arrangement } \\
\text { of obligations } \\
\text { in Indonesia } \\
\text { capital market } \\
\text { to provide } \\
\text { legal certainty } \\
\text { that is } \\
\text { equitable for } \\
\text { all people / } \\
\text { businesses in } \\
\text { Indonesia } \\
\text { capital market }\end{array}$ \\
\hline 5. & $\begin{array}{l}\text { Reconstructio } \\
\mathrm{n} \text { of Ideal } \\
\text { Value }\end{array}$ & $\begin{array}{l}\text { Reconstruction } \\
\text { ideal } \\
\text { implementatio } \\
\mathrm{n} \\
\text { arrangements } \\
\text { Indonesian } \\
\text { obligations in } \\
\text { the capital } \\
\text { market-based }\end{array}$ \\
\hline
\end{tabular}

\begin{tabular}{|l|l|}
\hline value of justice \\
is to restore \\
the purpose of \\
issuance and \\
execution of \\
obligation \\
trading in the \\
stock market \\
based on \\
values of \\
justice \\
dignified \\
Indonesia \\
based on \\
Pancasila.
\end{tabular}

Reconstruction of the Chairman of Bapepam-LK No. KEP-412 / BL / 2010 stipulated in Rule Number VI.C.4 on general provisions and trustee contract debt securities

\begin{tabular}{|c|c|c|c|}
\hline No. & $\begin{array}{c}\text { Beep } \\
\text { Before } \\
\text { Reconstr } \\
\text { uction }\end{array}$ & $\begin{array}{c}\text { Weaknes } \\
\text { s }\end{array}$ & $\begin{array}{c}\text { Beep After } \\
\text { Reconstru } \\
\text { ction }\end{array}$ \\
\hline 1. & $\begin{array}{l}\text { Decision } \\
\text { of } \\
\text { Chairman } \\
\text { of } \\
\text { Bapepam- } \\
\text { LK No. } \\
\text { KEP-412 / } \\
\text { BL / } 2010\end{array}$ & $\begin{array}{l}\text { In } \\
\text { Bapepam } \\
\text { regarding } \\
\text { trustee } \\
\text { agreement } \\
\text { in letter e. } \\
\text { warranties } \\
\text { (if any). }\end{array}$ & $\begin{array}{l}\text { Decision of } \\
\text { Chairman of } \\
\text { Bapepam-LK } \\
\text { No. KEP-412 } \\
\text { / BL / } 2010 \\
\text { stipulated in } \\
\text { Rule } \\
\text { Number }\end{array}$ \\
\hline
\end{tabular}




\begin{tabular}{|c|c|c|c|c|c|}
\hline 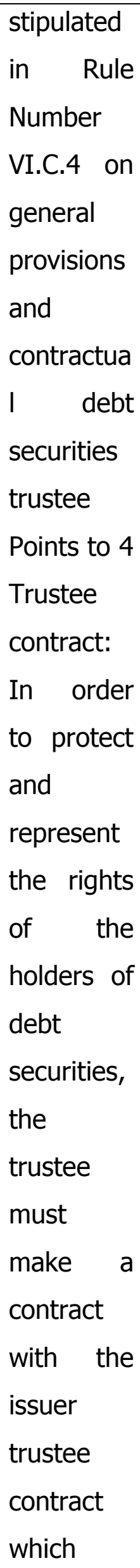 & 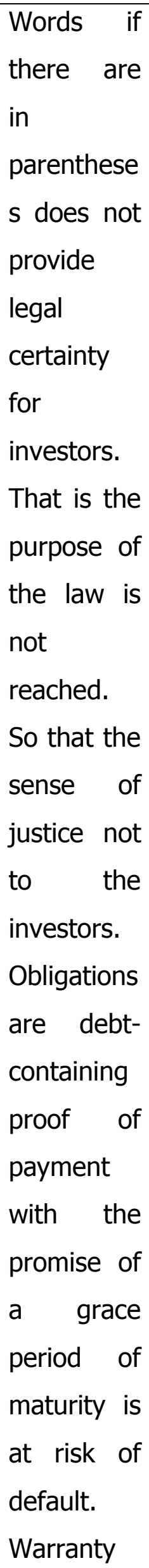 & $\begin{array}{l}\text { VI.C.4 on } \\
\text { general } \\
\text { provisions } \\
\text { and } \\
\text { contractual } \\
\text { debt } \\
\text { securities } \\
\text { trustee } \\
\text { Points to } 4 \\
\text { Trustee } \\
\text { contract: In } \\
\text { order to } \\
\text { protect and } \\
\text { represent } \\
\text { the rights of } \\
\text { the holders } \\
\text { of securities } \\
\text { debt, the } \\
\text { trustee must } \\
\text { make } \\
\text { contract } \\
\text { with } \\
\text { issuer } \\
\text { trustee } \\
\text { contract } \\
\text { which } \\
\text { contains at } \\
\text { least: } \\
\text { a. }\end{array}$ & $\begin{array}{l}\text { contains } \\
\text { at least: } \\
\text { a. The } \\
\text { identities } \\
\text { of the } \\
\text { parties } \\
\text { b. } \\
\text { principal } \\
\text { debt } \\
\text { c. } \\
\text { Maturing } \\
\text { entry } \\
\text { d. Flower } \\
\text { e. } \\
\text { Warrantie } \\
\text { s (if any) }\end{array}$ & 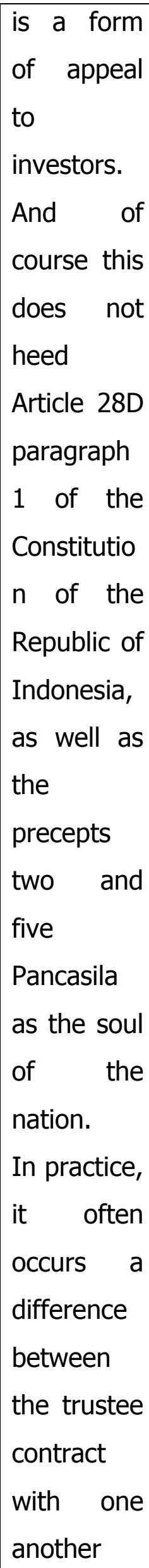 & $\begin{array}{l}\text { c. Maturing } \\
\text { entry } \\
\text { d. Flower } \\
\text { e. security }\end{array}$ \\
\hline
\end{tabular}




\begin{tabular}{|c|}
\hline 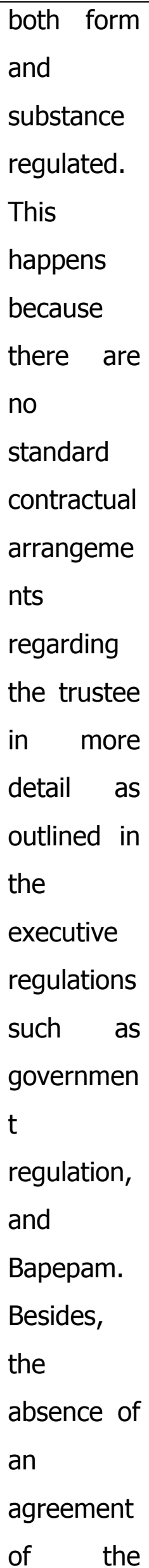 \\
\hline
\end{tabular}

\begin{tabular}{|c|c|c|c|}
\hline & & $\begin{array}{l}\text { parties } \\
\text { involved in } \\
\text { the } \\
\text { issuance of } \\
\text { debt } \\
\text { securities / } \\
\text { obligations } \\
\text { in } \\
\text { connection } \\
\text { with } \\
\text { charge of } \\
\text { trusteeship } \\
\text { contract, } \\
\text { both } \\
\text { issuers, } \\
\text { trustees, } \\
\text { notaries } \\
\text { and } \\
\text { lawyers. }\end{array}$ & \\
\hline 2. & $\begin{array}{l}\text { Decision } \\
\text { of } \\
\text { Chairman } \\
\text { of } \\
\text { Bapepam- } \\
\text { LK No. } \\
\text { KEP-412 / } \\
\text { BL / } 2010 \\
\text { stipulated } \\
\text { in Rule } \\
\text { Number } \\
\text { VI.C.4 on } \\
\text { general } \\
\text { provisions }\end{array}$ & $\begin{array}{l}\text { Unclear } \\
\text { rules on } \\
\text { liability } \\
\text { trustee in } \\
\text { terms of } \\
\text { compensat } \\
\text { ion to } \\
\text { investors } \\
\text { as a result } \\
\text { of } \\
\text { negligence } \\
\text {, both in } \\
\text { the Capital } \\
\text { Market }\end{array}$ & $\begin{array}{l}\text { Decision of } \\
\text { Chairman of } \\
\text { Bapepam-LK } \\
\text { No. KEP-412 } \\
\text { / BL / } 2010 \\
\text { stipulated in } \\
\text { Rule } \\
\text { Number } \\
\text { VI.C.4 on } \\
\text { general } \\
\text { provisions } \\
\text { and } \\
\text { contractual } \\
\text { debt }\end{array}$ \\
\hline
\end{tabular}




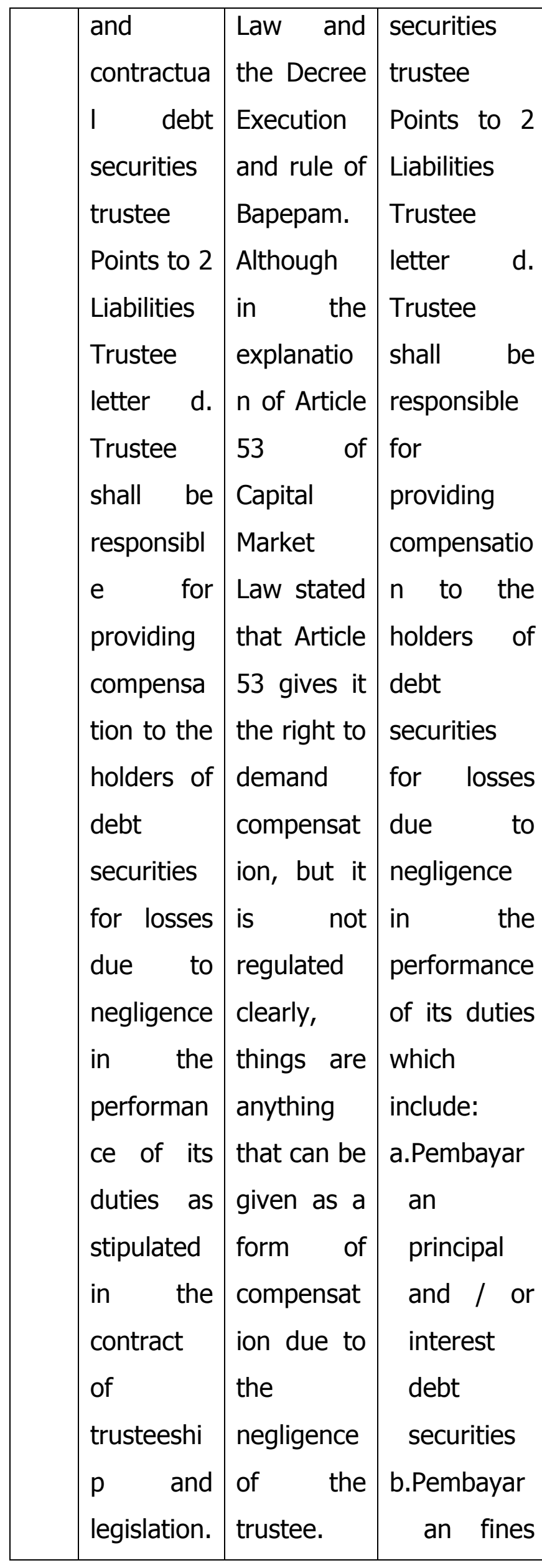

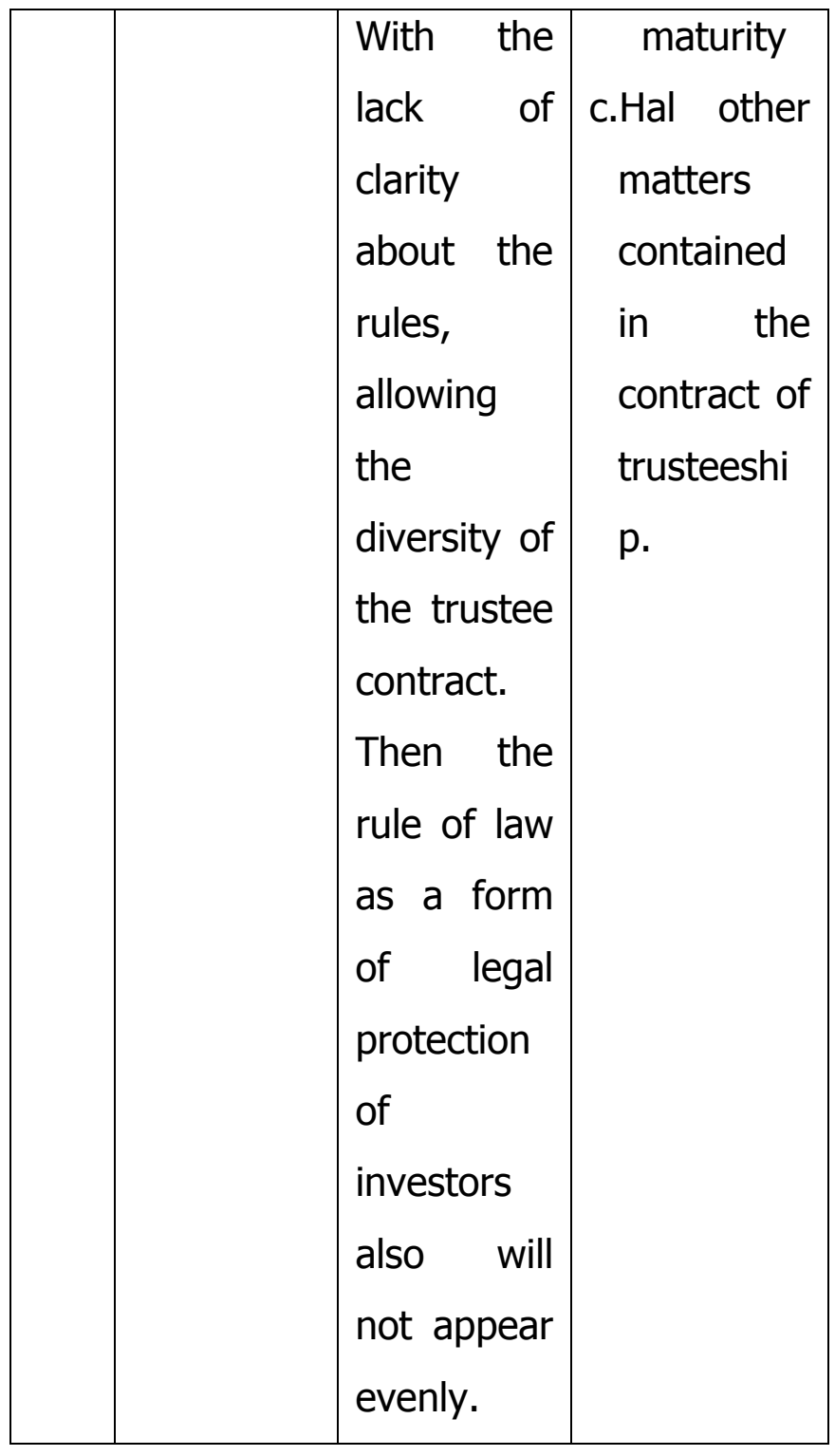

\section{CONCLUSION}

Reconstruction of BapepamLK's decision to restore the purpose of the issuance and execution of obligation trading in the stock market based on values of justice dignified Indonesia based on Pancasila and the 1945 Constitution substance of justice is not only accepted by obligation investors only, but also justice for the issuer and trustee as representing obligation investors interest in 
obtaining the right to continue its business activities or activities in the economic field. Reconstruction is done by changing the law of specific provisions of Bapepam Decree No. 412 in number 4 letter $E$ on collateral (if any), which is the implementing regulations of the Capital Market Act No. 8 of 1995. By removing / deleting the words in brackets (if any ), because they do not reflect the value of the rule of law and justice.
a. The identities of the parties
b. Principal debt
C. Maturing entry
d. Flower
e. Security
c. Other things contained in the contract of trusteeship. interest debt securities
b. Payment of fines maturity

Bapepam-LK No. KEP-412 / BL / 2010 stipulated in Rule Number VI.C.4 on general provisions and contractual debt securities trustee Points to 2 Liabilities Trustee letter $d$. Trustee shall be responsible for providing compensation to the holders of debt securities for losses due to negligence in the performance of its duties which include:

a. Payment of principal and / or

\section{BIBLIOGRAPHY}

\section{Books:}

Andre Ata Ujan, 2001, Keadilan dan Demokrasi: Telaah Filsafat Politik John Rawls, Kanisius, Yogyakarta;

B.N. Marbun, 1996, Kamus Politik, Pustaka Sinar Harapan, Jakarta

Elvira Fitriyani Pakpahan, 2017, Rekonstruksi Pengaturan Obligasi di Pasar Modal Indonesia Berbasis Keadilan, Semarang: Disertasi

Pers, Medan;

James P. Chaplin, 1997, Kamus Lengkap Psikologi, Raja Grafindo Persada, Jakarta;

Teguh Prasetyo, 2016, Pancasila The Ultimate of All the Sources of Laws (A Dignified Justice Perspective, Jurnal Internasional, The International Institute for Science, Technology and Education/ IISTE Bandung; 